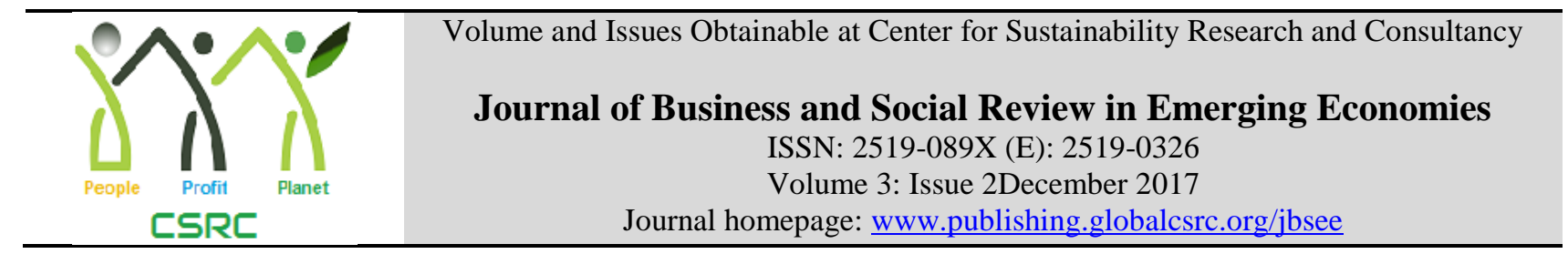

\title{
Antecedents of the User Behavior for Online Businesses: A Case of Pakistan
}

\author{
${ }^{1}$ Lutf Ullah, ${ }^{2}$ Muhammad Amjad Khan \\ ${ }^{1}$ Bahauddin Zakariya University, Multan, Pakistan khan.lutf01@gmail.com \\ ${ }^{2}$ University of Punjab, Lahore, Pakistan mamjadk83@yahoo.com
}

\begin{tabular}{l}
\hline ARTICLEDETAILS \\
\hline History \\
Revised format: Nov 2017 \\
AvailableOnline: Dec 2017
\end{tabular}

Keywords

Perceived Flow,

E-loyalty,

Technology Acceptance

Model,

Purchase Intentions,

Online businesses

JEL Classification:

O10, 014

\begin{abstract}
Purpose:This study tries to investigate the antecedents of user behavior like purchaseintentions and e-loyalty in the context of Pakistan. More specifically, it studies the relationship between perceived flow, perceived usefulness, perceived ease of use and the user behavior constructs which this study considers are e-loyalty and purchase intentions.

Design/Methodology/Approach:Primary Data is obtained through survey from 466 respondents and was analyzedthrough PLS-SEM approach.

Findings:Findings suggest that perceived flow and technological acceptance modelconstructs which are perceived ease of use and perceived usefulness have significant positive impact on the e-loyalty and purchase intentions in the developing economy like Pakistan.

Implications/Originality/Value:This study is a contribution to the literature acknowledging the importance offlow and technology acceptance model constructs as antecedents of user behavior for online businesses in the context of developing country like Pakistan.This study guides practitioners for designing such a website that make a user feel'flow' situation while surfing their website. If they are able to make their visitors feel flow, they are more likely to generate purchase intention and develop eloyalty for the e-vendor.
\end{abstract}

(C) 2017 The authors, under a Creative Commons AttributionNonCommercial 4.0

Corresponding author's email address: khan.lutf01@gmail.com

Recommended citation:Ullah, L. \&Khan, M. A., (2017).Antecedents of the user behavior for online businesses: A case of Pakistan. Journal of Business and Social Review in Emerging Economies, 3(2) 199-208.

DOI:https://doi.org/10.26710/jbsee.v3i2.43

\section{Introduction}

Loyalty has become a center of focus with in e-businesses due to the fact that consumers switch from the websites more frequently (Tsai, Huang, Jaw, \& Chen, 2006). It is important not only as a key strategy for the company, but it is also necessary for the websites in order to continue their operations over internet. This is emphasized by both, the practitioners and the academic researchers (Schefter \& Reichheld, 2000). Business forums have keen interest in the loyalty because of its importance in the electronic commerce. Academic community is also appealing for studies which will help both, the businesses and the academics communities to understand loyalty formation (Hsu, Wu, \& Chen, 2013). E-loyalty is explained usually by one factor, satisfaction, which is shown to be a major determinant of online environment and offline loyalty (Anderson \& Srinivasan, 2003). Previous researches indicate that satisfaction builds and maintains long term and loyal customer pool and then ultimately, results in the appropriate outcomes in the transactions over internet (Evanschitzky, Iyer, Hesse, \& Ahlert, 2004; Wu \& Chang, 2005). Moreover, it was found that satisfaction is an important antecedent for the loyalty over internet (Anderson \& 
Srinivasan, 2003; Chang, Wang, \& Yang, 2009). Many studies suggest that website's technology factors which are related to consumers' behavior and psychological state, influence the customer e-loyalty and esatisfaction. (Anderson \& Srinivasan, 2003; Shih, 2004). It has also been mentioned that Flow describes human-computer interface and thus, it is an important factor to determine online behavior of the user (Chang \& Zhu, 2012; Lee \& Tsai, 2010;Zhou \& Lu, 2011). Users feel joy and pleasure when they experience flow, which facilitates to get positive response from the online customer (Hoffman \& Novak, 1996). So, potential importance of flow cannot be disregarded (O'Cass \& Carlson, 2010). Hoffman and Novak (1996)concluded that chance of website's success depends upon the chances of users to experience flow.

Although researches have attempted to find the antecedents of the e-loyalty and purchase intentions in online context, but difference of the behavior of the visitor is kept unnoticed which requires to be addressed (Hsu, Chang, \& Chen, 2012). This study combines technological acceptance model with user's psychological state of mind using the website, like Perceived Flow and checks their combined impact on e-loyalty and purchase intentions.

This paper is organized in sections. Section 2 consists on definitions of variables and hypothesis development along with research model. Section 3 deals with the methodology while section 4 is related with data analysis and findings of the survey. Implications are presented in section 5 which is followed by research limitations in section 6.

\section{Literature Review}

\subsection{E-Service and E-Loyalty}

Anderson and Srinivasan (2003)said that satisfaction can be described as the experience through using a product or service. According to them, e-satisfaction is the pleasure or happiness in the online context for having a positive purchase experience from e-vendors. According to Evanschitzky et al. (2004), esatisfaction has gained much attention of the marketing studies in recent times. This is because satisfied persons are more likely to re-purchase from that e-commerce firm (H. Lee, Choi, \& Kang, 2009). Moreover, they have high degree of e-loyalty as compared to those consumers who are not satisfied (Anderson \& Srinivasan, 2003). Many researches have affirmed that e-satisfaction doesn't only develop and maintain a customer pool which is loyal to the firm (Evanschitzky et al., 2004), but it is also a major factor of online re-purchase intentions. (Bhattacherjee, 2001; Hsu, Yen, Chiu, \& Chang, 2006). Thus, for developing the e-loyalty for online business, they face a challenge of satisfying the consumer needs higher than the competitors (Oliver, 1999). According to Srinivasan, Anderson, and Ponnavolu (2002), e-loyalty can be described as the positive attitude of the consumer which results in the more purchases from the specific online business firm. However, according to Gremler (1995), that behavioral and attitudinal aspects must be taken into account while considering loyalty. Cyr, Bonanni, Bowes, and Ilsever (2005)concluded that loyal consumers are more likely to repurchase from the e-retailer in the future. Therefore, loyal customers have crucial importance for the website's financial outcomes (Schefter \& Reichheld, 2000).Heskett, Sasser, and Schlesinger (1997)proposed that a slight rise in the loyal customer percentage will lead a rise in profitability and then ultimately, a rise in the value of company. As attracting new customers to the website and then retaining it costs high and it is difficult (Schefter \& Reichheld, 2000), loyalty has crucial part in the success of an e-commerce firm (Heskett et al., 1997). Consequently, e-loyalty is taken as the dependent construct in this study.

\subsection{Purchase intentions}

Along with satisfaction of the customer, purchase intention of the customer is also important to consider as intentions predict the behavior of the customer. As per the findings of Zeithaml, Berry, and Parasuraman (1996), purchase intention is the dimension of behavior of the consumer. As purchase intention is linked with actual behavior, it is utilized for prediction of the customer behavior (Ajzen \& Fishbein, 1980). This relation is researched empirically in tourism and hospitality context (Ajzen \& Driver, 1992; Buttle \& Bok, 1996). Moreover, many studies have found this link in offline context too 
(Zeithaml, 2000). Boulding, Kalra, Staelin, and Zeithaml (1993)suggested that common dimensions of the behavior of a user is purchase/re-purchase intentions and purchase/re-purchase behavior. This study considers purchase intention as an important variable as during the visit by a user to a website, major challenge of the website is to make the visitor to be buyer. It is also important because revenue and profitability of a business is affected by purchase intentions. So, importance of purchase intentions as an outcome construct is clear and it is taken in this study as final dependent variable.

\subsection{Technology Acceptance Model (TAM)}

Davis (1989)proposed Technological Acceptance Model (TAM) which is regarded as a tool for analyzing consumer's information system for the new technology. Technological Acceptance Model comprises of two major constructs which are perceived ease of use and perceived usefulness. These constructs affects attitude and behavioral intentions of consumer when combined(Davis, Bagozzi, \& Warshaw, 1989). TAM is regarded as "parsimonious model with high explanatory power of the variance in users' behavioral intentions related to information system usage and adoption across a wide variety of contexts"(Taylor \& Todd, 1995). Many researches used TAM to define the usage of technology (Adams, Nelson, \& Todd, 1992; Davis, 1989; Fisk, Patricio, Lin, \& Chang, 2011; Kuo \& Yen, 2009; Taylor \& Todd, 1995). TAM has been used to assess the probability of the success of the technology and the factors behind acceptance of the technology (Kuo \& Yen, 2009). Davis (1989)explained the perceived ease of use as "the degree to which using the technology will be free of effort" and, perceived usefulness as "the level at which a person believes that the use of a technology will be beneficial for him". These factors of the TAM are regarded as important factors to influence the technology usage (Adams et al., 1992; Lu, Zhou, \& Wang, 2009). So, these factors of technology acceptance model will be considered in this study as independent variables.

\subsection{Perceived flow}

Flow is regarded as a useful tool to analyze consumer behavior with respect to technology (Hsu \& Lu, 2004; Novak, Hoffman, \& Yung, 2000). Perceived flow is an enjoyable condition of mind when a person uses a website as Chen, Wigand, and Nilan (1999) suggested that using a website may cause the development of flow. Researchers have found when a user of the website experiences flow, is attracted and it has positive impact on subsequent behavior and attitude of the user towards the website (Novak et al., 2000). Consequently, Mathwick and Rigdon (2004) proposed that flow has positive relation to the attitude towards website that leads to a user having intention of spending extra time on the website and revisit the website in future (Kabadayi \& Gupta, 2005). Thus, perceived flow is included in this study as independent variable.

\subsection{Hypothesis Development}

Analyzing the flow, Webster, Trevino, and Ryan (1993) concluded that perceived flow improves learning which affects the behavior and attitude of the user in online environment. Studies also found that positive flow will mitigate price consciousness, attract customers and affect the subsequent behaviors and attitudes positively (Novak et al., 2000). Specially, flow will positively affect the user attitude and behavior regarding the website (Mathwick \& Rigdon, 2004). According to O'Cass and Carlson (2010), flow develops the positive feelings for the site which leads to the satisfaction. So as a result of above arguments from the researchers, hypothesis is drawn as,

H1: Perceived flow affects customer satisfaction positively.

Studies have confirmed that perceived ease of use affects satisfaction of a user from the website significantly (Lin, 2008). Davis et al. (1989)concluded that improving ease of use will result in improvement of the business performance. According to Ajzen and Fishbein (1980), when a person is of the opinion that a behavior will result positively if he will have a positive attitude towards reforming that behavior and specially, he will be more likely to develop satisfaction from the website when he will perceive it as a useful (Bhattacherjee, 2001). Researchers also found that perceived usefulness 
significantly affects the satisfaction from a website (Arbaugh, 2000; Chiu, Lin, Sun, \& Hsu, 2009; Lin, 2008). From the above discussion, hypotheses can be drawn as,

H2: Perceived ease of use affects the e-satisfaction positively

H3: Perceived usefulness affects the e-satisfaction positively

As satisfied customers are the goal of the every business (Lin \& Ding, 2005), it is not the ultimate goal. Companies try to achieve it because it leads to e-loyalty and positive behavioral outcomes from the customer such as purchase intentions and then ultimately, leads to survival of the company (Gopalakrishna \& Mummalaneni, 1993). Empirical studies have identified the positive relation between the satisfaction and behavioral intentions (Zeithaml et al., 1996). According to Ju Rebecca Yen and Gwinner (2003), satisfaction from a technology has positive influence on behavioral outcomes like intentions to revisit the site and repurchase from the website. Shankar, Smith, and Rangaswamy (2003)tried to investigate the outcome of satisfaction and found that satisfaction led to loyalty towards the business. Bai, Law, and Wen (2008)proposed that purchase intentions are positively influenced by the satisfaction of the consumers. Therefore, hypothesis from the above discussion can be drawn as,

H4: Customer satisfaction affects the purchase intentions positively.

Satisfaction is generated in response to customer and business interaction experience and thus, it is an emotional status (Westbrook, 1981). Shankar et al. (2003)tried to investigate the outcome of satisfaction and found that satisfaction led to loyalty towards the business. This link has been verified empirically by Chang et al. (2009), Anderson and Sullivan (1993), Anderson and Srinivasan (2003), Chiu et al. (2009).

Therefore, following hypothesis can be drawn:

H5: E-satisfaction affects e-loyalty positively.

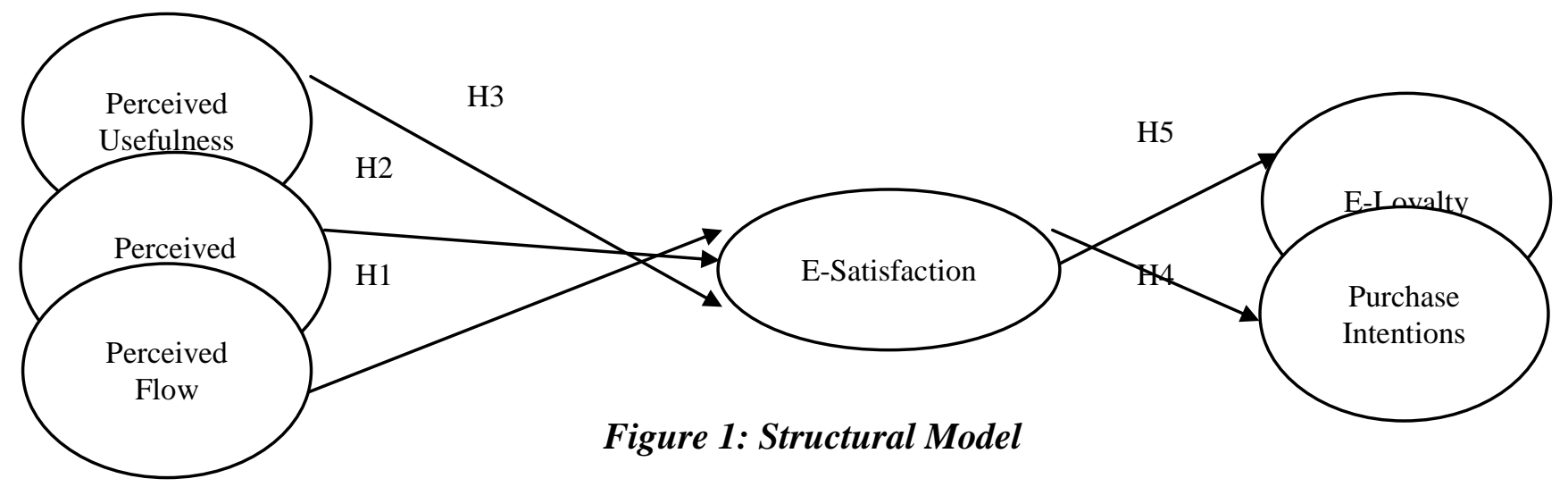

\section{Methodology}

Sample of this study was the online buyers from www.olx.com.pk because it is well advertised and well known in Pakistan. Respondents who had shopped at www.olx.com.pk in the previous 12 month were selected and were approached for the survey. A survey was designed for the respondents to find out how their online shopping behavior is shaped and whether they become loyal to an online store after a specific psychological situation or not. Data was collected by sending the questionnaire through social media. Data was collected from 466 respondents which was used to analyze the hypotheses through SmartPLS 3.

Measurement for variables of this research was done through adapting the questionnaire items from previous studies. Perceived Ease of Use and Perceived Usefulness measurement items were adapted from Koufaris (2002) which were measured through 3 and 4 items respectively. E-satisfaction was measured through adapting 5 items from Oliver (1999) and 6 items questionnaire was adapted from Zeithaml et al. (1996) and Gremler (1995) for e-loyalty. Purchase Intention of the customer were assessed by three items designed by Chen and Barnes (2007) and the Flow assessment way was consistent with Novak et al. (2000) having three items for measurement. These measures were then modified according to the need of 
this study and 7 point Likert Scale was used for getting the response from respondents.

\section{Results and Discussion}

From 466 responses, $59 \%$ responses were from female side and $41 \%$ responses were from male side while $45.27 \%$ were married and $54.72 \%$ were single. Age group of 25 to 34 represented the biggest portion of respondents having $40 \%$ share. Group of more time consumption over internet was 2 to 5 hours showing $50.42 \%$ of the sample. Majority of the respondents had used internet from 1 to 3 years representing 74\% share of the sample in our study.

Table 1: Demographic Analysis of the Respondents

\begin{tabular}{|c|c|c|}
\hline Variable & Count $(N)$ & Percentage \\
\hline \multicolumn{3}{|l|}{ Gender } \\
\hline Male & 275 & $59.01 \%$ \\
\hline Female & 191 & $40.98 \%$ \\
\hline \multicolumn{3}{|l|}{ Age } \\
\hline $18-24$ & 142 & $30.47 \%$ \\
\hline $25-34$ & 187 & $40.12 \%$ \\
\hline $35-44$ & 73 & $15.66 \%$ \\
\hline $45-54$ & 46 & $9.87 \%$ \\
\hline 55 and over & 18 & $3.86 \%$ \\
\hline \multicolumn{3}{|l|}{ Internet Experience } \\
\hline 1 to 3 year & 345 & $74.03 \%$ \\
\hline 3 to 5 year & 121 & $25.96 \%$ \\
\hline Over 5 year & 2 & $0.42 \%$ \\
\hline \multicolumn{3}{|l|}{ Daily Internet Use } \\
\hline Less than two hours & 123 & $26.39 \%$ \\
\hline 2 to 5 hours & 235 & $50.42 \%$ \\
\hline 5 to 7 hours & 53 & $11.37 \%$ \\
\hline More than 7 hours & 55 & $11.80 \%$ \\
\hline \multicolumn{3}{|l|}{ Marital status } \\
\hline Married & 211 & $45.27 \%$ \\
\hline Single & 255 & $54.72 \%$ \\
\hline
\end{tabular}

Internal consistency of the variables was checked through Cronbach's $\alpha$. As presented in table 2, its value is acceptable as it surpassed the minimum acceptable value of 0.7 which is recommended by Nunnally (1978). Therefore, reliability of the constructs in this study is acceptable. Factor loading was used for the constructs in order to assess the item reliability (Shih, 2004). The results showed that factor loading of the measures surpassed the 0.5 acceptable limit which conformed the item reliability (Hair, Black, Babin, Anderson, \& Tatham, 2006).

Table 2: Validity and Reliability Results

\begin{tabular}{|c|r|r|r|}
\hline Variables & Factor Loadings & Cronbach's $\alpha$ & $\begin{array}{r}\text { Average Variance Extracted } \\
\text { (AVE) }\end{array}$ \\
\hline E-Loyalty & & 0.940 & 0.737 \\
\hline L1 & 0.911 & & \\
\hline L2 & 0.900 & & \\
\hline L3 & 0.778 & & \\
\hline L4 & 0.804 & & \\
\hline L5 & 0.889 & & \\
\hline L6 & 0.896 & & \\
\hline E-Satisfaction & & & \\
\hline S1 & 0.865 & & \\
\hline S2 & 0.852 & & \\
\hline
\end{tabular}




\begin{tabular}{|c|c|c|c|}
\hline S3 & 0.812 & & \\
\hline S4 & 0.760 & & \\
\hline S5 & 0.916 & & \\
\hline Purchase Intentions & & 0.864 & 0.788 \\
\hline PI1 & 0.820 & & \\
\hline PI2 & 0.919 & & \\
\hline PI3 & 0.920 & & \\
\hline Perceived Flow & & 0.937 & 0.889 \\
\hline PF1 & 0.957 & & \\
\hline PF2 & 0.972 & & \\
\hline PF3 & 0.898 & & \\
\hline Perceived Ease of Use & & 0.706 & 0.772 \\
\hline PE1 & 0.888 & & \\
\hline PE3 & 0.870 & & \\
\hline Perceived Usefulness & & 0.785 & 0.619 \\
\hline PU1 & 0.851 & & \\
\hline PU2 & 0.731 & & \\
\hline PU3 & 0.930 & & \\
\hline PU4 & 0.594 & & \\
\hline
\end{tabular}

In addition, average variance extracted, which is the measurement of convergent validity (Fornell \& Larcker, 1981) has surpassed the 0.5 acceptable value limit as presented in Table 2 . To assess the degree to which variables differ, discriminant validity was utilized. If the square root of average variance extracted of a construct is higher than its correlation with another variable, , it is regarded as the construct has the discriminant validity. Inter-correlations among variables of this study are displayed in Table 3 which shows that discriminant validity is acceptable as correlation of the variables does not exceed the squared average variance explained.

Table 3: Fornell-Larcker Test

\begin{tabular}{|l|r|r|r|r|r|r|}
\hline & $\begin{array}{l}\text { E- } \\
\text { Loyalty }\end{array}$ & E-Satisfaction & $\begin{array}{l}\text { Perceived } \\
\text { Ease of use }\end{array}$ & $\begin{array}{l}\text { Perceived } \\
\text { Flow }\end{array}$ & $\begin{array}{l}\text { Perceived } \\
\text { usefulness }\end{array}$ & $\begin{array}{l}\text { Purchase } \\
\text { Intentions }\end{array}$ \\
\hline E-Loyalty & $\mathbf{0 . 9 5 8}$ & & & & & \\
\hline E-Satisfaction & 0.859 & $\mathbf{0 . 9 4 7}$ & & & & \\
\hline Perceived Ease of use & 0.920 & 0.843 & $\mathbf{0 . 9 6 3}$ & & & \\
\hline Perceived Flow & 0.874 & 0.935 & 0.867 & $\mathbf{0 . 9 4 3}$ & & \\
\hline Perceived usefulness & 0.866 & 0.924 & 0.919 & 0.863 & $\mathbf{0 . 9 3 6}$ & \\
\hline Purchase Intentions & 0.625 & 0.646 & 0.873 & 0.877 & 0.787 & $\mathbf{0 . 8 8 8}$ \\
\hline
\end{tabular}

Table 4 shows the predicting accuracy which is strong as the values are higher.Table 5 shows the results of the hypotheses that are gained using structural equation modeling. It represents the estimated coefficients which are significant at $95 \%$ confidence interval. As figure 2 shows, perceived ease of use, perceived usefulness and flow are positively linked with e-satisfaction thus affirming hypotheses $\mathrm{H} 1 \mathrm{H} 2$ and H3. Furthermore, path coefficients also show that e-satisfaction is also positively linked with the purchase intentions and e-loyalty. Thus, hypotheses $\mathrm{H} 4$ and $\mathrm{H} 5$ are also supported. All the relations are significant at $95 \%$ confidence level. 
Table 4: $\mathbf{R}^{2}$ (Predictive Accuracy)

\begin{tabular}{|l|r|r|}
\hline & \multicolumn{1}{|l|}{$\begin{array}{l}\text { Square } \\
\text { S }\end{array}$} & Predicting Accuracy \\
\hline E-loyalty & 0.754 & Strong \\
\hline Satisfaction & 0.737 & Strong \\
\hline
\end{tabular}

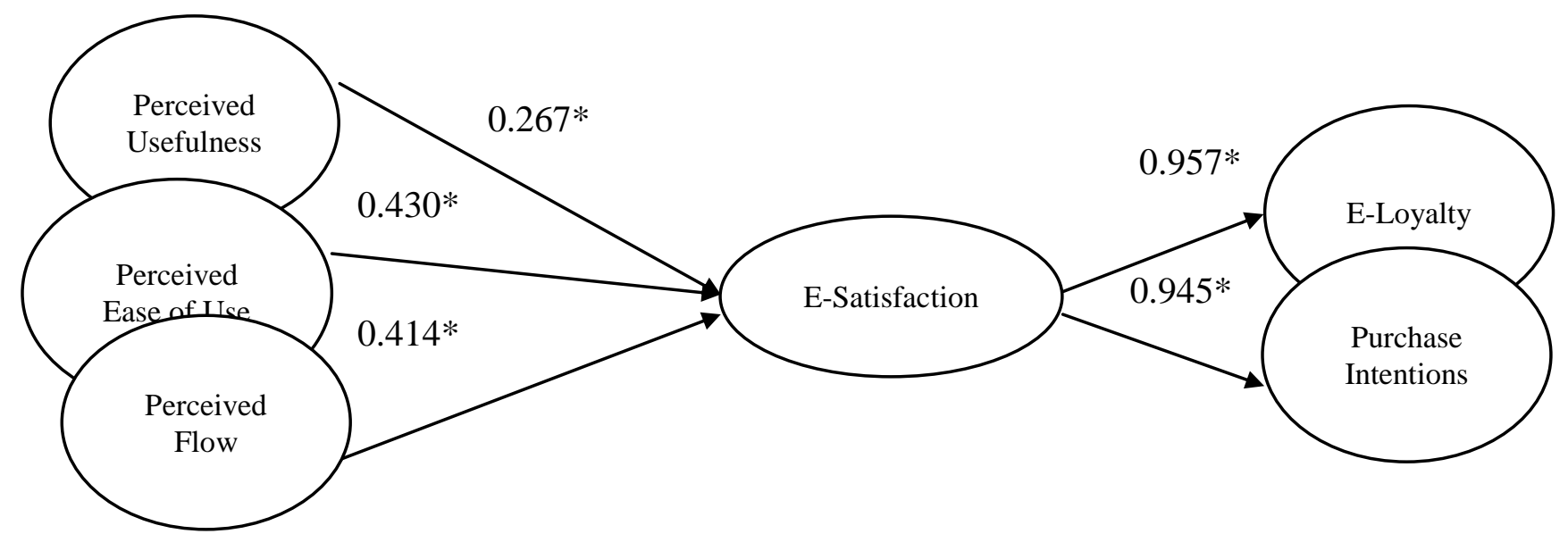

Figure 2: Structural Model Result

$*$ All relations are significant at p-value $<0.05$

According to the results of the analysis, all hypotheses were supported. Results supported that flow can predict the e-satisfaction. This means H1 is supported. This confirms the result reported by Shin (2006) who suggested that flow is significantly and positively associated with the e-satisfaction. This implies that when users of the website experiences flow while shopping online, it is more likely that feelings of satisfaction will be generated for the shopping website.Results also supported the $\mathrm{H} 2$ and $\mathrm{H} 3$ which means perceived ease of use and perceived usefulness are significantly and positively linked with the esatisfaction which is consistent with the studies of Lin (2008) and Arbaugh (2000) who proposed that perceived ease of use and perceived usefulness have significant positive influence on e-satisfaction.

Table 5: Path Coefficients

\begin{tabular}{|l|r|r|r|}
\hline Paths & Estimated Parameters & t value & \multicolumn{1}{l|}{ Result } \\
\hline E-Satisfaction -> E-Loyalty (H5) & 0.957 & 2.43 & Supported \\
\hline E-Satisfaction -> Purchase Intentions (H4) & 0.945 & 3.56 & Supported \\
\hline Perceived Ease of use -> E-Satisfaction (H2) & 0.430 & 5.45 & Supported \\
\hline Perceived Flow -> E-Satisfaction (H1) & 0.414 & 7.65 & Supported \\
\hline Perceived usefulness -> E-Satisfaction (H3) & 0.267 & 3.22 & Supported \\
\hline
\end{tabular}

Results of e-satisfaction on e-loyalty and purchase intention was also found to be positive and significant which supports H5 and H6. These results confirms the previous studies of Anderson and Srinivasan (2003) and Kim (2012) who have concluded that e-satisfaction is the key determinant of e-loyalty and purchase intentions for case of online shopping experience.

\section{Implications}

Theoretically, this study attempts to determine the role of flow along with technological acceptance model for online purchasing and e-loyalty. This research demonstrates that e-satisfaction is obtained when users of the website experience flow, perceive it easy and useful. E-satisfaction ultimately, leads to e-loyalty and purchase intentions which is the ultimate goal of the firm.

Practically, this study propose to the e-commerce companies that they should focus on intrinsic 
motivation of the consumer i.e. flow, which plays a significant role in website businesses (Hoffman \& Novak, 1996). Focus should be to build and maintain flow state for the customers as the users of the website will enjoy more and spend more time on the website. Additionally, businesses should try to design the website which increases the ease of use and usefulness perceptions to assist the flow state of the consumer to form e-satisfaction. This in turn, will have higher probability of turning the user into the buyer and creating loyalty. This suggests that customer's interaction with the website is useful and of key importance.

\section{Conclusion and Limitations}

Online businesses are striving for growth and sustainability in their businesses. There are many factors which affects the online businesses but psychological factors like perceived flow, perceived ease of use and perceived usefulness are the important factors. Conceptually, these factors lead to the satisfaction and then e-loyalty and purchase intentions are generated. This study verifies these relationships and provided some guidelines to the e-commerce firms that they should focus on the psychological factors of the customers while designing their website so that they should enjoy growth in the business and sustainability through e-loyalty.

Although this research has some useful implications for practitioners and academic researchers, it has some limitations. First, important variable of this study was flow which is multifaceted concept. But this study assesses it with only three items. Further research can be conducted using different dimensions of flow. Second, this study is conducted in Pakistan which is not in advance stage of online shopping. Results from the developed country will provide more insight. Finally, as consumer behavior is dynamic, longitudinal study will give more clear results.

\section{References}

Adams, D. A., Nelson, R. R., \& Todd, P. A. (1992). Perceived usefulness, ease of use, and usage of information technology: A replication. MIS quarterly, 227-247.

Ajzen, I., \& Driver, B. L. (1992). Application of the theory of planned behavior to leisure choice. Journal of leisure research, 24(3), 207.

Ajzen, I., \& Fishbein, M. (1980). Understanding attitudes and predicting social behaviour.

Anderson, E. W., \& Sullivan, M. W. (1993). The antecedents and consequences of customer satisfaction for firms. Marketing science, 12(2), 125-143.

Anderson, R. E., \& Srinivasan, S. S. (2003). E-satisfaction and e-loyalty: a contingency framework. Psychology and Marketing, 20(2), 123-138.

Arbaugh, J. B. (2000). Virtual classroom characteristics and student satisfaction with internet-based MBA courses. Journal of management education, 24(1), 32-54.

Bai, B., Law, R., \& Wen, I. (2008). The impact of website quality on customer satisfaction and purchase intentions: Evidence from Chinese online visitors. International Journal of Hospitality Management, 27(3), 391-402.

Bhattacherjee, A. (2001). Understanding information systems continuance: an expectation-confirmation model. MIS quarterly, 351-370.

Boulding, W., Kalra, A., Staelin, R., \& Zeithaml, V. A. (1993). A dynamic process model of service quality: from expectations to behavioral intentions. Journal of marketing research, 30(1), 7.

Buttle, F., \& Bok, B. (1996). Hotel marketing strategy and the theory of reasoned action. International Journal of Contemporary Hospitality Management, 8(3), 5-10.

Chang, H. H., Wang, Y.-H., \& Yang, W.-Y. (2009). The impact of e-service quality, customer satisfaction and loyalty on e-marketing: Moderating effect of perceived value. Total Quality Management, 20(4), 423-443.

Chang, Y. P., \& Zhu, D. H. (2012). The role of perceived social capital and flow experience in building users' continuance intention to social networking sites in China. Computers in Human Behavior, 28(3), 995-1001.

Chen, H., Wigand, R. T., \& Nilan, M. S. (1999). Optimal experience of web activities. Computers in Human Behavior, 15(5), 585-608. 
Chen, Y.-H., \& Barnes, S. (2007). Initial trust and online buyer behaviour. Industrial Management \& Data Systems, 107(1), 21-36.

Chiu, C.-M., Lin, H.-Y., Sun, S.-Y., \& Hsu, M.-H. (2009). Understanding customers' loyalty intentions towards online shopping: an integration of technology acceptance model and fairness theory. Behaviour \& Information Technology, 28(4), 347-360.

Cyr, D., Bonanni, C., Bowes, J., \& Ilsever, J. (2005). Beyond trust: Web site design preferences across cultures. Journal of Global Information Management (JGIM), 13(4), 25-54.

Davis, F. D. (1989). Perceived usefulness, perceived ease of use, and user acceptance of information technology. MIS quarterly, 319-340.

Davis, F. D., Bagozzi, R. P., \& Warshaw, P. R. (1989). User acceptance of computer technology: a comparison of two theoretical models. Management science, 35(8), 982-1003.

Evanschitzky, H., Iyer, G. R., Hesse, J., \& Ahlert, D. (2004). E-satisfaction: a re-examination. Journal of retailing, $80(3)$, 239-247.

Fisk, R. P., Patricio, L., Lin, J.-S. C., \& Chang, H.-C. (2011). The role of technology readiness in selfservice technology acceptance. Managing Service Quality: An International Journal, 21(4), 424 444.

Fornell, C., \& Larcker, D. F. (1981). Evaluating structural equation models with unobservable variables and measurement error. Journal of marketing research, 39-50.

Gopalakrishna, P., \& Mummalaneni, V. (1993). Influencing satisfaction for dental services. Marketing Health Services, 13(1), 16.

Gremler, D. D. (1995). The effect of satisfaction, switching costs, and interpersonal bonds on service loyalty. Arizona State University Tempe, AZ.

Hair, J. F., Black, W. C., Babin, B. J., Anderson, R. E., \& Tatham, R. L. (2006). Multivariate data analysis (Vol. 6): Pearson Prentice Hall Upper Saddle River, NJ.

Heskett, J., Sasser, W. E., \& Schlesinger, L. A. (1997). The Service Profit Chain: How Leading Companies Link Profit and Growth to Loyalty, Satisfaction, and Value (Цепочка создания прибыли в сфере услуг: как ведущие компании связывают прибыль и рост с лояльностью, удовлетворением и ценностью).

Hoffman, D. L., \& Novak, T. P. (1996). Marketing in hypermedia computer-mediated environments: conceptual foundations. The Journal of Marketing, 50-68.

Hsu, C.-L., Chang, K.-C., \& Chen, M.-C. (2012). The impact of website quality on customer satisfaction and purchase intention: perceived playfulness and perceived flow as mediators. Information Systems and e-Business Management, 10(4), 549-570.

Hsu, C.-L., \& Lu, H.-P. (2004). Why do people play on-line games? An extended TAM with social influences and flow experience. Information \& Management, 41(7), 853-868.

Hsu, C.-L., Wu, C.-C., \& Chen, M.-C. (2013). An empirical analysis of the antecedents of e-satisfaction and e-loyalty: focusing on the role of flow and its antecedents. Information Systems and eBusiness Management, 11(2), 287-311.

Hsu, M.-H., Yen, C.-H., Chiu, C.-M., \& Chang, C.-M. (2006). A longitudinal investigation of continued online shopping behavior: An extension of the theory of planned behavior. International Journal of Human-Computer Studies, 64(9), 889-904.

Ju Rebecca Yen, H., \& Gwinner, K. P. (2003). Internet retail customer loyalty: the mediating role of relational benefits. International Journal of Service Industry Management, 14(5), 483-500.

Kabadayi, S., \& Gupta, R. (2005). Website loyalty: an empirical investigation of its antecedents. International Journal of Internet Marketing and Advertising, 2(4), 321-345.

Kim, D. J. (2012). An investigation of the effect of online consumer trust on expectation, satisfaction, and post-expectation. Information Systems and e-Business Management, 10(2), 219-240.

Koufaris, M. (2002). Applying the technology acceptance model and flow theory to online consumer behavior. Information systems research, 13(2), 205-223.

Kuo, Y.-F., \& Yen, S.-N. (2009). Towards an understanding of the behavioral intention to use 3G mobile value-added services. Computers in Human Behavior, 25(1), 103-110. 
Lee, H., Choi, S. Y., \& Kang, Y. S. (2009). Formation of e-satisfaction and repurchase intention: Moderating roles of computer self-efficacy and computer anxiety. Expert Systems with Applications, 36(4), 7848-7859.

Lee, M.-C., \& Tsai, T.-R. (2010). What drives people to continue to play online games? An extension of technology model and theory of planned behavior. Intl. Journal of Human-Computer Interaction, 26(6), 601-620.

Lin, C.-P., \& Ding, C. G. (2005). Opening the black box: assessing the mediating mechanism of relationship quality and the moderating effects of prior experience in ISP service. International Journal of Service Industry Management, 16(1), 55-80.

Lin, H.-F. (2008). Antecedents of virtual community satisfaction and loyalty: an empirical test of competing theories. CyberPsychology \& Behavior, 11(2), 138-144.

Lu, Y., Zhou, T., \& Wang, B. (2009). Exploring Chinese users' acceptance of instant messaging using the theory of planned behavior, the technology acceptance model, and the flow theory. Computers in Human Behavior, 25(1), 29-39.

Mathwick, C., \& Rigdon, E. (2004). Play, flow, and the online search experience. Journal of consumer research, 31(2), 324-332.

Novak, T. P., Hoffman, D. L., \& Yung, Y.-F. (2000). Measuring the customer experience in online environments: A structural modeling approach. Marketing science, 19(1), 22-42.

Nunnally, J. (1978). Psychometric theory. Mc Graw-Hill Publ Co. New York.

O'Cass, A., \& Carlson, J. (2010). Examining the effects of website-induced flow in professional sporting team websites. Internet Research, 20(2), 115-134.

Oliver, R. L. (1999). Whence consumer loyalty? The Journal of Marketing, 33-44.

Schefter, P., \& Reichheld, F. (2000). E-loyalty: your secret weapon on the Web. Harvard Business Review, 78(4), 105-113.

Shankar, V., Smith, A. K., \& Rangaswamy, A. (2003). Customer satisfaction and loyalty in online and offline environments. International journal of research in marketing, 20(2), 153-175.

Shih, H.-P. (2004). An empirical study on predicting user acceptance of e-shopping on the Web. Information \& Management, 41(3), 351-368.

Shin, N. (2006). Online learner's 'flow'experience: an empirical study. British Journal of Educational Technology, 37(5), 705-720.

Srinivasan, S. S., Anderson, R., \& Ponnavolu, K. (2002). Customer loyalty in e-commerce: an exploration of its antecedents and consequences. Journal of retailing, 78(1), 41-50.

Taylor, S., \& Todd, P. A. (1995). Understanding information technology usage: A test of competing models. Information systems research, 6(2), 144-176.

Tsai, H. T., Huang, H. C., Jaw, Y. L., \& Chen, W. K. (2006). Why on-line customers remain with a particular e-retailer: An integrative model and empirical evidence. Psychology \& Marketing, 23(5), 447-464.

Webster, J., Trevino, L. K., \& Ryan, L. (1993). The dimensionality and correlates of flow in humancomputer interactions. Computers in Human Behavior, 9(4), 411-426.

Westbrook, R. A. (1981). Sources of consumer satisfaction with retail outlets. Journal of retailing, 57(3), 68-85.

Wu, J.-J., \& Chang, Y.-S. (2005). Towards understanding members' interactivity, trust, and flow in online travel community. Industrial Management \& Data Systems, 105(7), 937-954.

Zeithaml, V. A. (2000). Service quality, profitability, and the economic worth of customers: what we know and what we need to learn. Journal of the academy of marketing science, 28(1), 67-85.

Zeithaml, V. A., Berry, L. L., \& Parasuraman, A. (1996). The behavioral consequences of service quality. The Journal of Marketing, 31-46.

Zhou, T., \& Lu, Y. (2011). Examining mobile instant messaging user loyalty from the perspectives of network externalities and flow experience. Computers in Human Behavior, 27(2), 883-889. 